\title{
Breeding and Genetic Assessment of Some Quantitative Traits in Crosses Forage Pea (Pisum sativum L.)
}

\author{
Valentin Kosev \\ Breeding and Seed Production of Forage Crops, Institute of Forage Crops, Pleven, Bulgaria \\ Email: valkosev@hotmail.com
}

Received 4 January 2014; revised 4 February 2014; accepted 1 March 2014

Copyright (C) 2014 by author and Scientific Research Publishing Inc. This work is licensed under the Creative Commons Attribution International License (CC BY). http://creativecommons.org/licenses/by/4.0/ (c) (i) Open Access

\section{Abstract}

The trial was carried during 2011-2013 on the second experimental field of the Institute of forage Crops-Pleven, Bulgaria. Populations of $P_{1}, P_{2}, F_{2}$ and $F_{1}$ of the crosses Shtambovii $\times$ Pleven 10 and Rosacrono $\times$ Pleven 4 and their reciprocals were investigated. Heterosis for the investigated traits was found in the hybrids of $F_{1}$ generations. The cross Rosacrono $\times$ Pleven 4 had the highest positive true heterosis for plant height $(31.54 \%)$, height to first pod $(15.44 \%)$ and pod length (17.11\%); the cross Shtambovii $\times$ Pleven 10-for nods per plant $(56.10 \%)$ and pod width (20.38\%); Pleven $10 \times$ Shtambovii-for 1000 seeds mass (14.65\%) and Pleven $4 \times$ Rosacrono-for number of seeds per pod. In $F_{2}$ the plants from Rosacrono $\times$ Pleven 4 had the strongest depression for plant height $(28.26 \%)$, height to first pod $(27.74 \%)$ and pod length $(18.13 \%)$; Shtambovii $\times$ Pleven $10-$ for 1000 seeds mass $(32.22 \%)$ and number of seeds per pod $(13.87 \%)$. The stability of the studied characters was determined. Their variation in $F_{1}$ in the hybrid combination between Shtambovii and Pleven 10 was higher than $F_{1}$ of Rosacrono and Pleven 4. For more traits in direct crosses variability was found to be lower in relation to the reciprocal crosses in both combination. The genetical part in phenotipycal expression for height to first pod (Pleven $10 \times$ Shtambovii), pod length and number of seeds per pod (Pleven $4 \times$ Rosacrono) was relative high and existed probability for selection of homozygous genotypes in the generation $F_{2}$ and $F_{3}$. The mass phenotype selection for other traits can implement and will be more effective if it starts in later hybrid generations $\left(F_{6}-F_{7}\right)$ or through individual selection.

\section{Keywords}

Forage Pea; Heterosis; Dominance; Genetic Analysis; Inheritance; Yield Components 


\section{Introduction}

Field pea is an important crop among pulses in the country due to its multiple uses like vegetable, chola, besan, dal etc. Field pea plays an important role in improving protein in diet as its protein level reaches up to 40 per cent on dry weight basis. For achieving future improvement, there is a great need to develop high yielding cultivars. The plant breeder depends upon variability present in the material for the improvement of quantitative and qualitative characters and their mutual association with seed yield [1].

Yield and production are affected by one or several major genes and also by multiple gene interactions, the separation of these effects is of great importance to understand the expression at the phenotypic level and to predict the segregation of a cross evaluated in the field. This information is important to establish a crop strategy, in which a greater expression of the desired genes appears [2].

Genetic variation of phenological, morphological and yield traits, such as flowering, plant height and seed weight, can be the result of characteristic segregation coded by simple genes and also the interaction among multiple genes. The determination of genetic effects is of great importance to understand expression at the phenotypic level and to predict the segregation of characteristics when a cross between contrasting individuals is carried out [3], allowing the establishment of a cultivation strategy where a bigger expression of the desired genes is shown. A way to evaluate the genetic components of a population is by starting with the study of its genetic and environmental variance. Genetic variance can be divided into three components: additive variance, which is associated with the overall allele effects of the locus; dominance variance, due to the interaction of effects of the alleles in the locus and epistatic variance, due to the non-allelic interaction of two or more loci [4] [5].

In populations, generated from a cross between two pure parents, different methods have been proposed for the identification of the effects of genetic components on quantitative traits using lineal models of mixed distribution generated from generation means, variances and likelihood based techniques [6]. These types of models have been used in different crop species, evaluating different quantitative traits such as expression of dwarfism genes in rice [2] and seed quality in cotton [3]. Starting with these models, it has been possible to differentiate additive and dominant effects in specific genes that affect seed quality and plant height, stability of the genotype among different environments, to determine patterns of additive inheritance among maternal and embryo effects, and additive effects in oil content in cotton seeds to determine how susceptible it is to the environment. Often, generation mean models ignore or do not isolate the maternal effects contribution, producing a bias in the intent to understand the genetics of a given quantitative trait. In some studies environments were analyzed separately which gives, in some cases, marked differences inside a non-segregate generation evaluated in different environments. This could generate an increase in the error variance of the generation means, producing non-valid estimators generated by this method [7] [8].

The aim of the present investigation was to determine the character of inheritance, degree of gene interactions and genetic part in the phonotypical expression of some quantitative traits in forage pea populations by using genetic analysis with a view to the rational carry out of selection.

\section{Materials and Methods}

The experimental study was conducted during the 2011-2013 period in second experimental field of the Institute of Forage Crops, Pleven, Bulgaria. The parent-form used for crossing were from our collection: spring forms (Pisum sativum ssp. sativum)-Shtambovii and Pleven 4, winter types (Pisum sativum ssp. arvense)-Rosacrono and Pleven 10.

The characteristics of these varieties were reported in Table 1. These forms were crossed by hand in 2011. The parental forms $\left(\mathrm{P}_{1}\right.$ and $\left.\mathrm{P}_{2}\right)$ and first and second generation $\left(\mathrm{F}_{1}\right.$ and $\left.\mathrm{F}_{2}\right)$ were sown at scheme $\mathrm{P}_{1}, \mathrm{P}_{2}, \mathrm{~F}_{2}, \mathrm{~F}_{1}$ on a row spacing $70 \mathrm{~cm}$ and distance in a row $5 \mathrm{~cm}$. Hand planting was applied with depth of sowing $5 \mathrm{~cm}$. The forage pea was grown by approved technology of the Institute of Forage Crops, Pleven. Direct and reciprocals crosses were included: Shtambovii $\times$ Pleven 10, Pleven $10 \times$ Shtambovii, Rosacrono $\times$ Pleven 4 and Pleven $4 \times$ Rosacrono. Inheritance of quantitative traits was analyzed-plant height $(\mathrm{cm})$, height to first pod (cm), nods per plant, pod length (cm), pod width (mm), 1000 seeds mass (g), and number of seeds per pod of parental components $\left(P_{1}\right.$ and $\left.P_{2}\right)$ and crosses of first and second hybrid generation $\left(F_{1}\right.$ and $\left.F_{2}\right)$. Twenty plants from $P_{1}, P_{2}, F_{1}$, and $F_{2}$ were analyzed. For each trait were determined: mean and variability (VC, \%) [9], heterosis effect in $F_{1^{-}}$ hypothetical and true and depression [10], degree of dominance in $\mathrm{F}_{1}\left(\mathrm{~h}_{\mathrm{p} 1}\right)$ and in $\mathrm{F}_{2}\left(\mathrm{~h}_{\mathrm{p} 2}\right)$ [11]; degree of trans- 
Table 1. Origin and description of pea genotypes.

\begin{tabular}{ccccc}
\hline Variety & Pleven 10 & Pleven 4 & Shtambovii & Rosacrono \\
Origin & Bulgaria & Bulgaria & Russia & Russia \\
Vine type & long-prostrate & long semi-erect & short semi-erect & long semi-erect \\
Flower position & axial & axial & terminal (with fasciation-fa, fac) & terminal (with fasciation-fa, Fac) \\
Stipule type & normal & normal & double & double \\
Leaf type & normal & normal & normal & normal \\
Flower color & purple & white & white & pink \\
Plant height, cm & $78^{\mathrm{d}}$ & $98^{\mathrm{c}}$ & $34^{\mathrm{a}}$ & $134^{\mathrm{b}}$ \\
Height to first pod, cm & $65^{\mathrm{d}}$ & $56^{\mathrm{b}}$ & $27^{\mathrm{a}}$ & $80^{\mathrm{c}}$ \\
Nods per plant & $20.47^{\mathrm{ab}}$ & $12.68^{\mathrm{b}}$ & $4.2^{\mathrm{a}}$ & $11.64^{\mathrm{ab}}$ \\
Pod length, cm & $5.94^{\mathrm{a}}$ & $5.61^{\mathrm{a}}$ & $5.37^{\mathrm{a}}$ & $5.78^{\mathrm{a}}$ \\
Pod width, mm & $13^{\mathrm{ab}}$ & $10^{\mathrm{ab}}$ & $9^{\mathrm{a}}$ & $10^{\mathrm{ab}}$ \\
1000 seeds mass $(\mathrm{g})$ & 229.81 & 121.60 & 175.67 & 142.78 \\
Number seeds per pod & $3.61^{\mathrm{b}}$ & 3.78 & $2.56^{\mathrm{a}}$ & 3.32 \\
\hline
\end{tabular}

a , b, c, d statistically proven differences in $\mathrm{P}=0.05$.

gression (Tn) in $F_{2}$ [12], heritability coefficient in narrow-sense $\left(h^{2}\right)$ and broad sense $\left(H^{2}\right)$ [13] in $F_{2}$; epistasis (E), number of the genes which parental forms are distinguish between for the certain trait (N), coefficient of effectiveness of the selection of genotypes in trait's manifesting $\left(\mathrm{P}_{\mathrm{p}}\right)$ [14].

All experimental data were processed statistically with using the computer software MS Excel for Windows XP.

\section{Results}

The data for plant height (Table 2) showed that all hybrids displayed positive hypothetical heterosis and it was stronger expressed in the direct crosses Shtambovii $\times$ Pleven 10 and Rosacrono $\times$ Pleven 4 . The last cross was charachterized also with highest true heterosis (31.54\%) and high depression (28.26\%).

At the direct crosses the inheritance of this trait higher meaning play the domination, i.e. predominate the father's components, which determinate longer stem. At the reciprocal crosses there were an epistatic gene effects $\left(h_{\mathrm{p} 2}>h_{\mathrm{p} 1}\right)$. Similar was the inheritance of height to first pod. Exception was Pleven $4 \times$ Rosacrono, which was characterized with intermediate inheritance of the traits $\left(\mathrm{h}_{\mathrm{p} 1}=-0.01\right)$. In all hybrids there was plant's depression (from $0.73 \%$ to $27.74 \%$ ).

Epistatic gene effects prevail in nods per plant. All hybrids demonstrated high positive hypothetical heterosis. Especially for Shtambovii $\times$ Pleven 10 and its reciprocal, which true heterosis was also positive. Only Pleven 4 $\times$ Rosacrono is characterized with positive value of the parameter depression. Negative domination $\left(h_{p 1}>h_{p 2}\right)$ was for pod width in Pleven $4 \times$ Rosacrono where dominate genes of variety Rosacrono. This cross reveal also the lowest negative heterosis. Positive were the heterosis behaviour of the hybrids of Shtambovii and Pleven 10 independently of the cross direction, which showed the highest depression also (from $-1.17 \%$ to $8.57 \%$ ). In the other hybrid combinations the inheritance was epistatic. The degree of dominance for pod length show, that the inheritance was negative dominant to over-dominant at Pleven 4 with Rosacrono and epistatic at Shtambovii with Pleven 10. The hybrids demonstrated positive heterosis and relative high depression for this trait with exception of Shtambovii $\times$ Pleven $10(-0.6 \%)$.

The character 1000 seeds mass was inherited semi-dominant at combination with the participation of Rosacrono and Pleven 4. In the rest hybrids this trait was inherited positive dominant and over-dominant. Positive hypothetical heterosis effect (from $4.71 \%$ to $26.49 \%$ ) as and depression were established in all hybrids. The combination Shtambovii with Pleven 10 was showed positive true heterosis. At almost all hybrids (without 
Table 2. Biometrical data of the quantitative traits of the investigated crosses.

\begin{tabular}{|c|c|c|c|c|c|c|c|}
\hline \multirow{2}{*}{ Hybrids } & \multirow{2}{*}{$\mathrm{F}_{1}$} & \multirow{2}{*}{$\mathrm{F}_{2}$} & \multicolumn{2}{|c|}{ Heterosis $\mathrm{F}_{1}(\%)$} & \multirow{2}{*}{$\begin{array}{l}\text { Depression } \\
\mathrm{F}_{2}(\%)\end{array}$} & \multicolumn{2}{|c|}{ Degrees of dominance } \\
\hline & & & Hypothetical & Real & & in $F_{1}\left(h_{p 1}\right)$ & in $F_{2}\left(h_{p 2}\right)$ \\
\hline \multicolumn{8}{|c|}{ Plant height } \\
\hline Shtambovii $\times$ Pleven 10 & $123.90^{*}$ & 102.15 & 47.68 & -7.26 & 17.55 & 0.80 & 0.73 \\
\hline Pleven $10 \times$ Shtambovii & 104.50 & 106.75 & 24.55 & -21.78 & -2.15 & 0.41 & 0.92 \\
\hline Rosacrono × Pleven 4 & $129.50^{*}$ & 92.90 & 46.53 & 31.54 & 28.26 & 4.08 & 0.9 \\
\hline Pleven 4 × Rosacrono & 96.63 & 100.60 & 9.34 & -1.85 & -4.11 & 0.82 & 2.43 \\
\hline \multicolumn{8}{|c|}{ Height to first pod } \\
\hline Shtambovii $\times$ Pleven 10 & 73.95 & 62.50 & 38.87 & -7.04 & 15.48 & 0.79 & 0.70 \\
\hline Pleven $10 \times$ Shtambovii & 61.85 & 61.40 & 16.15 & -22.25 & 0.73 & 0.33 & 0.62 \\
\hline Rosacrono × Pleven 4 & $75.15^{*}$ & 54.30 & 24.27 & 15.44 & 27.74 & 3.17 & -2.67 \\
\hline Pleven 4 × Rosacrono & 60.42 & 53.00 & -0.09 & -7.19 & 12.28 & -0.01 & -3.23 \\
\hline \multicolumn{8}{|c|}{ Nods per plant } \\
\hline Shtambovii $\times$ Pleven 10 & 18.16 & 19.86 & 129.46 & 56.10 & -9.37 & 2.75 & 6.42 \\
\hline Pleven $10 \times$ Shtambovii & 17.88 & $22.07^{*}$ & 125.85 & 53.64 & -23.48 & 2.68 & 7.61 \\
\hline Rosacrono × Pleven 4 & 20.39 & $24.91^{*}$ & 23.03 & -0.39 & -22.19 & 0.98 & 4.28 \\
\hline Pleven $4 \times$ Rosacrono & 20.46 & 18.88 & 23.45 & -0.05 & 7.74 & 1.00 & 1.18 \\
\hline \multicolumn{8}{|c|}{ Pod width } \\
\hline Shtambovii $\times$ Pleven 10 & 11.48 & 10.50 & 24.87 & 20.38 & 8.57 & 6.67 & 7.61 \\
\hline Pleven $10 \times$ Shtambovii & 11.24 & 11.38 & 22.33 & 17.93 & -1.17 & 5.99 & 12.75 \\
\hline Rosacrono × Pleven 4 & 11.11 & $12.98^{*}$ & -5.20 & -14.77 & -16.86 & -0.46 & 1.92 \\
\hline Pleven 4 × Rosacrono & 10.63 & 10.94 & -9.22 & -18.39 & -2.85 & -0.82 & -1.18 \\
\hline \multicolumn{8}{|c|}{ Pod length } \\
\hline Shtambovii $\times$ Pleven 10 & 5.75 & 5.99 & 3.11 & -0.60 & -4.20 & 0.83 & 3.99 \\
\hline Pleven $10 \times$ Shtambovii & 6.16 & 5.96 & 10.47 & 6.50 & 3.12 & 2.81 & 3.77 \\
\hline Rosacrono × Pleven 4 & 6.95 & 5.69 & 20.48 & 17.11 & 18.13 & 7.13 & -0.95 \\
\hline Pleven $4 \times$ Rosacrono & 6.66 & 5.47 & 15.36 & 12.14 & 17.89 & 5.35 & -3.67 \\
\hline \multicolumn{8}{|c|}{1000 seeds mass } \\
\hline Shtambovii $\times$ Pleven 10 & 187.14 & 126.84 & 17.53 & 6.53 & 32.22 & 1.70 & -3.94 \\
\hline Pleven $10 \times$ Shtambovii & 201.40 & 162.22 & 26.49 & 14.65 & 19.45 & 2.56 & 0.36 \\
\hline Rosacrono × Pleven 4 & 186.61 & 178.76 & 6.21 & -18.80 & 4.21 & 0.20 & 0.11 \\
\hline Pleven 4 × Rosacrono & 183.98 & 169.39 & 4.71 & -19.94 & 7.93 & 0.15 & -0.23 \\
\hline \multicolumn{8}{|c|}{ Number seeds per pod } \\
\hline Shtambovii $\times$ Pleven 10 & 3.46 & 2.98 & 17.69 & 4.22 & 13.87 & 1.37 & 0.21 \\
\hline Pleven $10 \times$ Shtambovii & 3.54 & 4.45 & 20.41 & 6.63 & -25.71 & 1.58 & 7.95 \\
\hline Rosacrono × Pleven 4 & 4.34 & 4.48 & 17.46 & 14.81 & -3.23 & 7.59 & 18.47 \\
\hline Pleven $4 \times$ Rosacrono & 4.50 & 4.36 & 21.79 & 19.05 & 3.11 & 9.47 & 15.65 \\
\hline
\end{tabular}

*Statistically proven differences between reciprocal crosses in $\mathrm{P}=0.05$. 
Shtambovii $\times$ Pleven 10 positive over-dominance) number of seeds per pod was inherited under influence epistatic gene actions.

Despite, that settled positive true heterosis, its value between separately hybrids very high (from $4.22 \%$ in Shtambovii $\times$ Pleven $10 \%$ to $19.05 \%$ in Pleven $4 \times$ Rosacrono), which results are different level of depression. In Pleven $10 \times$ Shtambovii and Rosacrono $\times$ Pleven 4, it was the lowest and negative. From of the negative values for degree of transgression (Table 3) at all hybrids for plant height, height to first pod and pod width can assume,

Table 3. Values of the gene parameters for the quantitative traits of the investigated crosses.

\begin{tabular}{|c|c|c|c|c|c|c|}
\hline \multirow{2}{*}{ Crosses/Indicators } & \multicolumn{6}{|c|}{ Gene parameters } \\
\hline & $\mathrm{Tn}$ & $\mathrm{H}^{2}$ & $h^{2}$ & $\mathrm{~N}$ & $\mathrm{E}$ & $\mathrm{P}_{\mathrm{p}}$ \\
\hline \multicolumn{7}{|c|}{ Plant height } \\
\hline Shtambovii × Pleven 10 & -27.10 & $0.47^{*}$ & $0.31^{*}$ & 0.74 & 0.48 & -0.25 \\
\hline Pleven $10 \times$ Shtambovii & -20.17 & $0.37^{*}$ & $0.25^{*}$ & 61.25 & -15.95 & -5.65 \\
\hline Rosacrono $\times$ Pleven 4 & -18.44 & $0.03^{\mathrm{ns}}$ & $0.01^{\mathrm{ns}}$ & 55.09 & 10.18 & 0.25 \\
\hline Pleven 4 × Rosacrono & -13.72 & $0.003^{\mathrm{ns}}$ & - & 62.10 & -15.58 & -4.42 \\
\hline \multicolumn{7}{|c|}{ Height to first pod } \\
\hline Shtambovii × Pleven 10 & -28.09 & $0.38^{*}$ & $0.26^{*}$ & 0.61 & 0.43 & 0.09 \\
\hline Pleven $10 \times$ Shtambovii & -27.42 & $0.39^{*}$ & $0.26^{*}$ & 2.76 & -1.25 & 0.32 \\
\hline Rosacrono × Pleven 4 & -36.83 & $0.24^{*}$ & $0.18^{*}$ & 50.12 & 10.96 & -0.22 \\
\hline Pleven 4 × Rosacrono & -46.44 & $0.44^{*}$ & $0.29^{*}$ & 14.25 & 4.06 & -0.02 \\
\hline \multicolumn{7}{|c|}{ Nods per plant } \\
\hline Shtambovii × Pleven 10 & 69.11 & $0.52^{*}$ & $0.33^{*}$ & 40.44 & -10.76 & -3.36 \\
\hline Pleven $10 \times$ Shtambovii & 74.43 & $0.72^{*}$ & $0.41^{*}$ & 173.63 & -41.88 & -13.81 \\
\hline Rosacrono $\times$ Pleven 4 & -5.39 & $0.15^{*}$ & $0.11^{*}$ & 14.76 & -4.28 & -0.36 \\
\hline Pleven 4 × Rosacrono & -39.46 & $0.14^{*}$ & $0.10^{*}$ & 3.97 & -1.72 & -1.59 \\
\hline \multicolumn{7}{|c|}{ Pod width } \\
\hline Shtambovii × Pleven 10 & -7.60 & $0.04^{\mathrm{ns}}$ & $0.01^{\mathrm{ns}}$ & 1.33 & -0.77 & 0.67 \\
\hline Pleven $10 \times$ Shtambovii & -6.76 & $0.03^{\mathrm{ns}}$ & $0.01^{\mathrm{ns}}$ & 0.14 & -0.19 & 0.71 \\
\hline Rosacrono $\times$ Pleven 4 & -36.72 & $0.01^{\mathrm{ns}}$ & $0.01^{\mathrm{ns}}$ & 99.48 & 18.94 & 0.41 \\
\hline Pleven 4 × Rosacrono & -38.95 & $0.12^{*}$ & $0.08^{*}$ & 38.58 & -9.25 & -0.89 \\
\hline \multicolumn{7}{|c|}{ Pod length } \\
\hline Shtambovii × Pleven 10 & 7.39 & $0.38^{*}$ & $0.26^{*}$ & 13.44 & -4.00 & -0.37 \\
\hline Pleven $10 \times$ Shtambovii & 7.82 & $0.34^{*}$ & $0.24^{*}$ & 6.51 & -2.32 & -0.08 \\
\hline Rosacrono $\times$ Pleven 4 & -35.08 & $0.001^{\mathrm{ns}}$ & - & 710.88 & -147.95 & -26.50 \\
\hline Pleven $4 \times$ Rosacrono & -44.40 & $0.40^{*}$ & $0.27^{*}$ & 1.75 & 0.91 & 0.23 \\
\hline \multicolumn{7}{|c|}{ Number seeds per pod } \\
\hline Shtambovii × Pleven 10 & 9.53 & $0.02^{\mathrm{ns}}$ & - & 0.13 & -0.13 & 0.24 \\
\hline Pleven $10 \times$ Shtambovii & 32.37 & $0.21^{\mathrm{ns}}$ & $0.05^{*}$ & 21.49 & -5.91 & -0.88 \\
\hline Rosacrono $\times$ Pleven 4 & 23.62 & $0.20^{*}$ & $0.15^{*}$ & 7.90 & -2.67 & -0.12 \\
\hline Pleven $4 \times$ Rosacrono & 22.94 & $0.14^{*}$ & $0.11^{*}$ & 2.78 & -1.26 & 0.18 \\
\hline
\end{tabular}

${ }^{*} \mathrm{P}=0.05$; ns: not significantly different. 
that in decompose generations from the available homozygous genotypes higher percent will be lower from initial forms and with more narrow pods. At Pleven $4 \times$ Rosacrono among homozygous plants probably will prevail these with height typical for parents. For number nods per plant only at Shtambovii $\times$ Pleven 10 and Pleven $10 \times$ Shtambovii $(69.11 \%$ and $74.43 \%)$ can expect homozygous genotypes with higher values for these traits. This probably was due of the rich inheritable base of the parent's forms. As regards of pod length only Shtambovii $\times$ Pleven 10 and its reciprocal exhibit positive degree of transgression and in follow generations can obtain plants with longer pods. For seeds per pod in all hybrids can expect homozygous plants with increased number seeds. The part from common variability conditioned from genetic differences was determined through using coefficient of heritability-broad-sense $\left(\mathrm{H}^{2}\right)$ and narrow $\left(\mathrm{h}^{2}\right)$. The inheritance is characterization of the relative part of the genetic differences and these which are result of the action of the environment in the phenotypic diversity. At change of genotype or the environment follow and variation of the assessment for inheritability. For all investigated traits (Table 3) coefficient in narrow sense was lower than broad-sense. With comparatively high value for this trait distinguish the hybrids between Shtambovii and Pleven 10 for plant height, height to first pod, nods per plant and pod length. Low and mean inheritability was established for pod width and number seeds per pod for all hybrids. The participant in crosses parental components distinguish for number of genes at the most traits which probably was due the hereditary data of initial varieties participate in the selection of the parents as the mother's effect of the cytoplasm. Were obtained and essential differences in this indicator between direct and reciprocal crosses for plant height, height to first pod, nods per plant and number seeds per pod at Shtambovii with Pleven 10 and pod width and length at Rosacrono with Pleven 4. At analysis of the indicator inter-alleles interaction (Table 3) in second generation was visible that part of the investigated traits the epistasis was negative and can admit that this will decrease the degree of their phenotype activity in relation with the full additive inheritance. There were presence positive epistatic interactions at Shtambovii $\times$ Pleven 10 (0.48; 0.43 for plant height, height to first pod, at Rosacrono $\times$ Pleven 4 for the same traits $(10.18$; 10.96) as and for pod width (18.94) and Pleven $4 \times$ Rosacrono for height to first pod (4.06) and pod length (0.91), which activate in direction to increase of the phenotype expression of the traits.

The quantitative traits determine the productiveness characterize with continuous variability due of the fact that the parent's varieties used that the parent's varieties use in hybridization scheme contain alleles of different genes of given polygene series. As much as contrasting initial forms in their phenotype, the hybrids will combine more different alleles of genes from respective polygene series. In all hybrids, the variability of the followed traits was tested by VC\%, characterizing the phenotypic diversity (Figure 1).
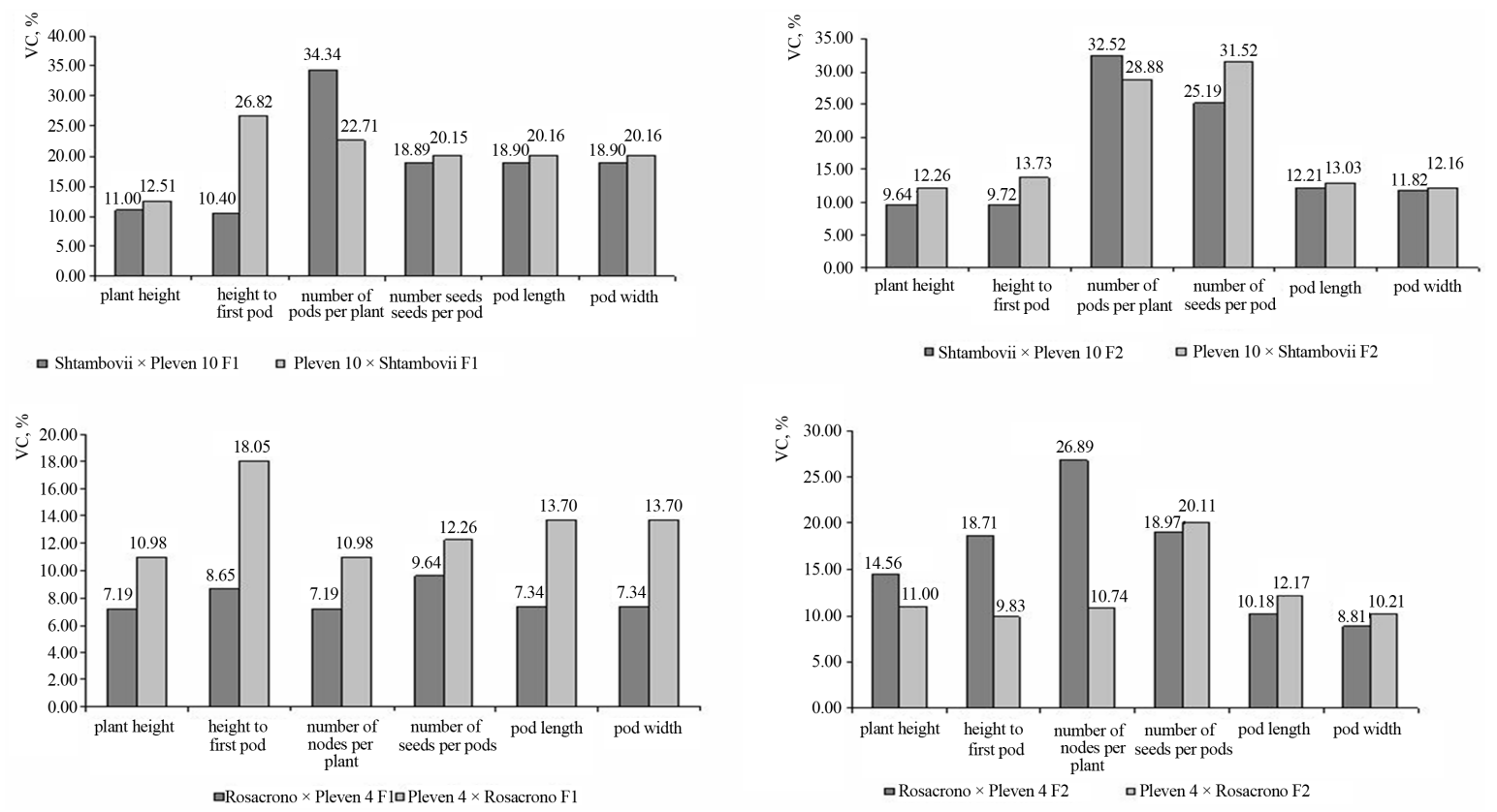

Figure 1. Coefficients of variability (VC, \%) in $F_{1}$ and $F_{2}$ pea progenies. 
The variation was considered low, if VC was $10 \%$, medium, if VC was between $10 \%$ and $20 \%$, and high, if VC was higher than $20 \%$, respectively. The CV values varied in a different way depending on crosses and traits. The level of variability of the traits in $\mathrm{F}_{1}$ in hybrids between Shtambovii and Pleven 10 was higher (from $10.40 \%$ for height to first pod to $34.34 \%$ for number nods per plant) than $\mathrm{F}_{1}$ of the other hybrid combination (from $7.19 \%$ for plant height to $18.05 \%$ for height to first pod). At direct crosses the variability was lower in relation with reciprocals and in both hybrids combinations with exception for nods per plant in Pleven $10 \times$ Shtambovii. In the second generation $F_{2}$ highest range of the variability was established for nods per plant and number seeds per pod in all hybrids exception Pleven $4 \times$ Rosacrono (10.74\%). Positive values of the coefficients for effectiveness of selection were established for height plant (0.25) at Rosacrono $\times$ Pleven 4, height to first pod at Shtambovii $\times$ Pleven 10 and reciprocal $(0.09$; 0.32), pod length at Pleven $4 \times$ Rosacrono $(0.23)$, number seeds per pod at Shtambovii $\times$ Pleven $10(0.24)$ and Pleven $4 \times$ Rosacrono (0.18) and for pod width at all hybrids with exception of Pleven $4 \times$ Rosacrono.

\section{Discussion}

The obtained experimental data were in agreement with published results by other authors [15], which reported for behavior of negative or feebly positive heterosis for these traits. In studying of the heritability on height to first pod at soy-bean hybrids [16] establish different type of inheritance-from over-dominance to absence on such. Similar heritability was observed at part of reciprocal crosses, which the authors give of the influence of cytoplasm inheritance factors. Reference [17] reported for activity of negative heterosis for 1000 seed mass and for different (positive and negative) for seed weight per plant. Reference [1] reported for high coefficient of variation in seed weight per plant, moderate for days to $50 \%$ flowering and plant height, whereas other traits (number branches per plant, seeds per pod, pods per plant and days to maturity) registered low coefficient of variation. Reference [18] also reported high coefficient of variation for yield, plant height, number of primary branches per plant and pod weight. Reference [19] also reported high coefficient of variation for seed yield per plant followed by pod per plant whereas [20] reported high coefficient of variation for plant height.

Obtained values for coefficients of heritability confirm results by other authors [21] [22], which reported for moderate to high inheritance of investigated from them quantitative traits (plant height, seeds per pod and pods per plant).

According them comparatively low difference between the coefficient of heritability in narrow and broad sense probably indicates that the genetic diversity for these traits is strongly inheritable and that the selection by phenotype may be effective and in follow generations could separate consolidate forms with desired trait's parameters.

The coefficients of heritability and of effectiveness of selection for height to first pod at Pleven $10 \times$ Shtambovii, pod length and number seeds per pod at Pleven $4 \times$ Rosacrono were relative high, which give reason to suppose that realy probability for selection of homozygous genotypes on their phenotype is high. The mass selection at these hybrids for pointed traits can start more in $F_{2}-F_{3}$. As sub-regard values of the gene parameters for the other traits as and the established coefficients can expect better results if at these traits through mass selection choose desired genotypes in later hybrid generations $\left(\mathrm{F}_{6}-\mathrm{F}_{7}\right)$ or through used of individual selection (pedigree procedure).

\section{Conclusion}

In the hybrids from first generations $F_{1}$ was found activities of heterosis for the investigated traits. With the highest positive true heterosis were characterized Rosacrono $\times$ Pleven 4 for plant height (31.54\%), height to first pod (15.44\%) and pod length (17.11\%), Shtambovii $\times$ Pleven 10 (56.10\%) for nods per plant and pod width (20.38\%), Pleven $10 \times$ Shtambovii for 1000 seeds mass (14.65\%) and Pleven $4 \times$ Rosacrono for number seeds per pod. In $\mathrm{F}_{2}$ with the strongest depression were plants from Rosacrono $\times$ Pleven 4 for plant height (28.26\%), height to first pod (27.74\%) and pod length (18.13\%), Shtambovii $\times$ Pleven 10 for 1000 seeds mass (32.22\%) and number seeds per pod (13.87\%). The stability of the studied characters was determined. Their variation in $\mathrm{F}_{1}$ in the hybrid combination between Shtambovii and Pleven 10 was higher than $\mathrm{F}_{1}$ of Rosacrono and Pleven 4. For more traits in direct crosses variability was found to be lower in relation to the reciprocal crosses in both combination. The genetical part in phenotipycal expression for height to first pod (Pleven $10 \times$ Shtambovii), pod length and number of seeds per pod (Pleven $4 \times$ Rosacrono) was relative high and existed probability for selec- 
tion of homozygous genotypes in the generation $\mathrm{F}_{2}$ and $\mathrm{F}_{3}$. The mass phenotype selection for other traits can implement and will be more effective if it starts in later hybrid generations $\left(\mathrm{F}_{6}-\mathrm{F}_{7}\right)$ or through individual selection. Were selected perspective hybrid forms (Pleven $10 \times$ Shtambovii and Pleven $4 \times$ Rosacrono) with new morphological and physiological characteristic. In the future, the selection will be evaluated their suitability for using as green forage and seed yield.

\section{References}

[1] Tiwari, G. and Lavanya, G. R. (2012) Genetic Variability, Character Association and Component Analysis in F4 Generation of Fieldpea (Pisum sativum var. arvense L.). Karnataka Journal of Agricultural Sciences, 25, 173-175.

[2] Jiang, C., Pan, X. and Gu, M. (1994) The Use of Mixture Models to Detect Effects of Major Genes on Quantitative Characters in a Plant Breeding Experiment. Genetics, 136, 383-394.

[3] Lou, X.Y. and Zhu, J. (2002) Analysis of Genetic Effects of Major Genes and Polygenes on Quantitative Traits. I. Genetic Model for Diploid Plants and Animals. Theoretical and Applied Genetics, 104, 414-421. http://dx.doi.org/10.1007/s001220100692

[4] Martínez, O. (1999) Conceptos y Principios de Genética Cuantitativa con Aplicación al Mejoramiento de Especies Vegetales. Faculty of Agronomy, Universidad Nacional de Colombia, Bogota.

[5] Hussein, M.A. and Aastveit, A.H. (2000) A Sas Program for Computing Genotype Environment Stability Statistics. Agronomy Journal, 92, 454-459. http://dx.doi.org/10.2134/agronj2000.923454x

[6] Kearsey, M.J. and Pooni, H.S. (1996) The Genetical Analysis of Quantitative Traits. Chapman and Hall, London. http://dx.doi.org/10.1007/978-1-4899-4441-2

[7] Rodríguez-Herrera, R., Rooney, W.L., Rosenow, D.T. and Frederiksen, R.A. (2000) Inheritance of Grain Mold Resistance in Grain Sorghum without a Pigmented Testa. Crop Science, 40, 1573-1578. http://dx.doi.org/10.2135/cropsci2000.4061573x

[8] Zalapa, J.E., Staub, J.E. and McCreight, J.D. (2006) Generation Means Analysis of Plant Architectural Traits and Fruit Yield in Melon. Plant Breed, 125, 482-487. http://dx.doi.org/10.1111/j.1439-0523.2006.01273.x

[9] Dimova, D. and Marinkov, E. (1999) Experimental Work and Biometrics. Academic Publishing House of the Agricultural University, Plovdiv, 193-205.

[10] Omarov, D.S. (1975) Towards the Methods of Plant Heterosis Recording and Assessment, Agricultural Biology, 10, 123-127.

[11] Romero, G.E. and Frey, K.J. (1973) Inheritance of Semi-Dwarfness in Several Wheat Crosses. Crop Science, 3, 334337. http://dx.doi.org/10.2135/cropsci1973.0011183X001300030015x

[12] Voskresenskaya, G.S. and Shpota, V.I. (1967) Transgressiya Priznakov u Gibridov Brassica i Metodika Kolichestvennogo Ucheta etogo Yavleniya. Doklady VASHNIL, 7, 18-20.

[13] Konstantinov, G., Belcheva, R., Ralchev, K. and Enova, G. (1979) Handbook for Practical Genetics. 173-178 (Bulgarian).

[14] Sobolev, N.A. (1976) Hybridological Analysis of Polygenic Traits. Cytology and Genetics, 10, 424-436.

[15] Borah, H.K. (2009) Studies on Combining Ability and Heterosis in Field Pea. Legume Research, 32, 255-259.

[16] Kostylev, P.I. and Vershinin, A.N. (2010) Plant Height Inheritage and Lower Bean Insertion in Soybean Hybrid $F_{1 .}$ Grain Economy of Russia, 5, 20-25.

[17] Espinosa, N. and Ligarreto, G.A. (2005) Evaluating Combinatory Ability and Heterosis of Seven Parental Pisum sativum L. Agronomia Colombiana, 23, 197-206.

[18] Kumar, A., Jain, B.P. and Kumar, A. (2003) Genetic Variability in Pea (Pisum sativum L.). Journal of Research, Birsa Agricultural University, 15, 55-59.

[19] Sharma, A.K., Singh, S.P. and Sharma, M.K. (2003) Genetic Variability, Heritability and Character Association in Pea (Pisum sativum L.). Crop Research, 26, 135-139.

[20] Sorphi, S.P.S., Yadav, R. and Malik, S. (2006) Genetic Variability, Correlations and Path Analysis for Seed Yield and Its Component Characters in Pea (Pisum sativum L.). Plant Archives, 6, 737-740.

[21] Singh, M.N. and Singh, R.B. (1989) Genetic Analysis of Yield Traits in Pea. Journal of Crop Improvement, 16, 62-67.

[22] Shinde, K. (2000) Genetic Parameters of Some Quantitative and Qualitative Traits in Pea (Pisum sativum L.). Orissa Journal of Horticulture, 28, 21-24. 